\title{
WOMEN MIGRANT WORKERS AND SOCIAL PROTECTION SYSTEMS IN THE PHILIPPINES
}

\author{
Purwowibowo \\ Social Welfare Department, Faculty of Social and Political Sciences, \\ University of Jember, Jember East Java, Indonesia \\ poerwowibowo@yahoo.co.id
}

\begin{abstract}
Women migrant workers from Philippines often face a variety of problems in the workplace, especially in overseas. For example, they face violence, sexual abuse, rape, extortion, and so on. Thus, social protection systems for women migrant workers in other countries are very important. In the Philippines, there are two social protection systems to improve social welfare for vulnerable populations. The two models of social protection are called health care system and social health insurance. Both social protection systems can be managed based on: (1) cultural value, (2) etablishment by financial institutions, (3) flexibility in implementation, (4) integratability of the scheme with the national health insurance system, (5) ability to create a high quality service. The condition of women migrant workers are more vulnerable than that of male workers. In addition, the social protection for women migrant workers is urgent and needs policies to protect them. The government of the Philippines emphasizes the problems related to the obligation of women migrant workers to have right information and guidance before they leave the country in order to minimize social problems. Finally, social protection is made not only in the Philippines but also by cooperation among countries to protect women migrant workers by making policies of social protection at local, national, regional, and international levels.
\end{abstract}

\section{Keywords: Women Migrant Worker, Social Protection, Philippines, Health Care System, Social Health Insurance}

\section{Introduction}

In 2013, the Commission on Filipinos Overseas (CFO) estimated that approximately 10.2 million people of Filipino descent lived or worked abroad (CFO, 2015). One of them is an employment such as a Women Migrant Worker (WMW). It's an employment conditions abroad and relevant to the individual worker and their families as well as for the sending country and its economic growth and well being. In overseas, poor working conditions for Filipinos hired abroad include long hours, low wages and few chances to visit family. WMW often face disadvantages and slavery in their employment conditions as they tend to work in the elder or child care and domestic sector such as servant in family. These occupations are considered low skilled and require little education and training then regularly facing poor working conditions. WMW facing just working conditions are more likely to provide their children with adequate nutrition, better education and sufficient health on the contrary with them (Oishina, N., 2002). There is a strong correlation between women's rights for MWM and the overall well being of children. It is therefore a in central question to promote women's rights in order to promote children's capabilities. According to a statement of Leomard, J. (2009), the Middle East coordinator of Migrante, a Manila-based Overseas Federation Women Organization (OFWO), every year, an unknown number of Filipinos in Saudi Arabia were then "victims of sexual abuses, maltreatment, unpaid salaries, and other labor malpractices.

Philippine Labor Migration Policy (PLMP), has historically focused on removing barriers for WMW to increase accessibility for employment abroad. Workplace and working conditions among Filipinos employed abroad varies depending on whether the host country acknowledges and enforces International Labor Orgnization (ILO) standards. The standards are set by the ILO and United Nation (UN) agency that labor standards vary greatly depending on host country regulations and enforcement. One of the main reasons for the large differences in labor standards is due to the fact that ILO and UN only can register complaints and not impose sanctions on governments that is a hos of WMW. 
Table 1: Area and Population

\begin{tabular}{lcc}
\hline Country & $\begin{array}{c}\text { Land } \\
\mathbf{( 1 0 0 0} \\
\left.\mathbf{k m}^{2}\right)\end{array}$ & $\begin{array}{c}\text { Population } \\
\text { (million) } \\
\mathbf{2 0 1 5}\end{array}$ \\
\hline Brunei & 5.8 & 0.434 \\
\hline Indonesia & 1,891 & 265.510 \\
\hline Philippines & 300 & 103.796 \\
\hline
\end{tabular}

Source: Worldometers. World Population Prospects: The 2015 Revision.

The establishment of the Asia South East Nation of Economic Community (AEC) in 2015 is a major milestone in the regional economic integration agenda, offering opportunities in the form of a huge market of US\$2.6 trillion and over 622 million people. In 2014, AEC was collectively the third largest economy in Asia and the seventh largest in the world. By the charter and establishing official cooperation and institutional framework, and then formulating goals and basic principles AEC. Some of them were intended for: (1) creating a single market and production based on the conditions of each country, prosperity, high competition and economic integration that effectively facilitate the trade and investment, facilitating entrepreneurs, professionals, talents and labor, capital flows, and (2) reducing poverty and reducing the development gap among members through mutual help and cooperation (Uriarte, F. A., 2009).

\section{Table 2: Economic Performance}

\begin{tabular}{lcc}
\hline Country & $\begin{array}{c}\text { GDP per } \\
\text { capita(USD) } \\
\mathbf{2 0 1 5}\end{array}$ & $\begin{array}{c}\text { GDP Total } \\
\text { ( USD) 2012 }\end{array}$ \\
\hline Brunei & 79,587 & 16,954 \\
\hline Indonesia & 11,126 & 878,043 \\
\hline Philippines & 7,254 & 250,182 \\
\hline
\end{tabular}

Source: IMF (2015) and ASEAN Economies (2012)

Compared with the European Community, for example, the whole ASEAN area reaches 4.5 million square kilometers, which is wider than the territory of the European Community. In 2007, its population had reached more than 576 million. There are two countries that have large areas, namely Indonesia and Phillipine while the smallest country region is Brunai and Singapore. Furthermore, two countries that have a large number of populations are Indonesia and the Philippines. Meanwhile, religions that exist in the region are Islam, Buddha, Christian and Hindu.
There are different forms of government; monarchy, presidential and parliamentary while the use of the language and the dialect varies (CIA, 2017).

Some of countries are aware that the socioeconomic conditions of their member countries are still unbalanced, that the difference in socioeconomic conditions is very striking and that there are countries which have high per capita income (Brunei and Singapore) but some other countries have per capita income less than 10,000 dollars. Two countries, namely Singapore and Brunei, have high per capita income compared to the other countries, and even country like Indonesia and Phillipine has very low per capita income. This very noticeable difference certainly indicates the socio-economic conditions of those countries (Table 2).

Under these conditions, some countries still requires a lot of cooperation to improve the quality of life, especially from disadvantaged communities, espicially WMW in the various member countries. The commitment is to encourage cooperation in social development which aims to improve a decent life for disadvantaged groups and villagers, finding and developing various sectors in community, especially women, youth, and local communities. It is also emphasized on the need of the issues related to the elderly, which not only requires a social policy but also economic policy and realization.

Generally, the cooperation is done in order to continue the economic development and improvement of social welfare which is emphasized on the issues related to social risks faced by children, women migrant worker, elderly and people with disability. The implementation of economic development and social welfare development programs significantly emphasizes the services to the elderly, early childhood care, and people with disabilities by establishing government institutions and non-government organizations (NGO) as its working partner.

According SEKNAS FITRA (2015), the development program has been launched in accordance with Millenium Development Goal Sustainable (MDGs) which was initiated by the United Nations (UN), namely (1) reducing poverty and hunger; (2) improving education; (3) gender equality; (4) children health; (5) maternal health; (6) combating HIV/AIDs; (7) environmental sustainability; (8) global cooperation, (9) improve budgeting for helth, and (10) reviced population data base. In addition, another challenge that needs to be broken down is a policy to reduce poverty, ensuring economic 
growth, resulting in sustainability and equity, building social cohesion, the challenge of high technological change with fast acceleration, globalization and democratization, building economic and financial resilience of regional and global financial crisis. National development strategies of each members country must also consider those who benefited and those who suffered losses in the development process, guaranteeing the vulnerable and minorities and minimizing the negative impacts of development activities undertaken.

Tabel 3 HDI Rank

\begin{tabular}{rcccc}
\hline Contries & $\begin{array}{c}\text { Rank } \\
\mathbf{2 0 1 2}\end{array}$ & $\begin{array}{c}\text { Rank } \\
\mathbf{2 0 1 5}\end{array}$ & $\begin{array}{c}\text { HDI } \\
\mathbf{2 0 1 2}\end{array}$ & $\begin{array}{c}\text { HDI } \\
\mathbf{2 0 1 5}\end{array}$ \\
\hline Singapura & 23 & 11 & 0,944 & 0,912 \\
\hline Brunei & 32 & 31 & 0.820 & 0,856 \\
\hline$\underline{\text { Philippines }}$ & 105 & 115 & 0.751 & 0,668 \\
\hline Indonesia & 111 & 110 & 0.734 & 0,684 \\
\hline
\end{tabular}

Source: Human Development Index (HDI) Report (2012 and 2015).

By the HDI (2012), two countries, namely Singapore and Brunei Darussalam, rank 11 and 32. Otherwise the positions of Philippines and Indonesia, are above rank 100 (Table 3). It also indicates that income, education, and life expectancy of people in the four countries vary and even can be called unbalanced. Of course, those does not close its eyes to such conditions but tries hard, instead, through mutual cooperation to economic development and social development, so that inequality of socioeconomic conditions can thus be reduced. In addition, according to socio-economic conditions of four as described above, especially of Phillipine's can be seen that there are many problems faced by the countries in many aspects of life which make many people especially the women want to become migrant worker in the overseas.

By looking at the problems above, this paper is intended to discuss the social protection about WMW in the Philippines.

\section{Methods}

The writing of this article uses secondary data mainly related to the population, socio-economic, socio-cultural, and employment conditions of Phillipine country. Various scientific articles that have been published in various scientific journals and that exist on the internet. In addition, some theoretical framework materials are derived from published textbooks. The content analysis of all articles and books is used to describe WMW and their social protection models in the Philippines. The analysis mostly uses the source triangulation method, i.e. one source of information compared to other source of similar information.

Thus, the 'mainstream' of the policies taken by the Philippine government can be known in the conduct of social protection against WMW. Under such protection schemes, emerging problems with it's can be addressed, or at least the risk of violations of the human rights of women working abroad or other countries can be minimized.

\section{Result and Discussion 3.1 Women Migran Worker in Philippine}

According Wikipedia (2012), The Philippine Labor Migration Policy (PLMP) of the Philippine government allows and encourages emigration. The Department of Foreign Affairs, which is one of the government's arms of emigration, grants Filipinos passports that allow entry to foreign countries. The Philippine government enacted the Migrant Workers and Overseas Filipinos Act of 1995 (Republic Act 8042) in order to "institute the policies of overseas employment and establish a higher standard of protection and promotion of the welfare of WMW and their families and overseas Filipinos in distress.

Table 4. Profile Philippine Migrant Worker

\begin{tabular}{ccccc}
\hline \multicolumn{3}{c}{ The Stock } & Estimate of Overseas & \multicolumn{2}{l}{ Filipinos. } \\
\hline Year & Permanent & Temporary & Irregular & Total \\
\hline 2000 & $2,551,549$ & $2,991,125$ & $1,840,448$ & $7,383,122$ \\
\hline 2001 & $2,736,528$ & $3,049,622$ & $1,625,936$ & $7,412,086$ \\
\hline 2002 & $2,807,356$ & $3,167,978$ & $1,607,171$ & $7,582,504$ \\
\hline 2003 & $2,865,412$ & $3,385,001$ & $1,515,765$ & $7,766,178$ \\
\hline 2004 & $3,187,586$ & $3,559,257$ & $1,297,005$ & $8,043,848$ \\
\hline 2005 & $3,931,138$ & $3,654,727$ & 881,123 & $8,466,988$ \\
\hline 2006 & $3,556,035$ & $3,802,345$ & 874,792 & $8,233,172$ \\
\hline 2007 & $3,692,256$ & $4,133,970$ & 900,023 & $8,726,250$ \\
\hline 2008 & $3,907,842$ & $3,626,259$ & 653,609 & $8,187,710$ \\
\hline 2009 & $4,056,940$ & $3,846,068$ & 658,370 & $8,561,378$ \\
\hline 2010 & $4,423,680$ & $4,324,388$ & 704,916 & $9,452,984$ \\
\hline 2011 & $4,867,645$ & $4,513,171$ & $1,074,972$ & $10,455,788$ \\
\hline 2012 & $4,925,797$ & $4,221,041$ & $1,342,790$ & $10,489,628$ \\
\hline 2013 & $4,869,766$ & $4,207,018$ & $1,161,830$ & $10,238,614$ \\
\hline Source
\end{tabular}

Source: Philippine Labor Migrant Policy.

Wikipedia 2012.

Among the Filipino migrants, there is a significant amount of migrants that are Overseas Filipino Workers (Wikipedia, 2012). One of the recent trends in Filipino contractual workers is that as years pass by, more and more women have traveled out of the country, outnumbering the men. This can be attributed to the fact that domestic helpers and entertainers are in-demand globally. In fact entertainers destined for Japan 
and other countries have increased from $3.3 \%$ to $18.9 \%$ in a span of a decade from 1983-1984. As of 2009, the most Filipinos work as household service workers. Out of the total of 71,557 household workers, 69,669 are women. According to the Philippine Statistics Authority (PSA, 2012), many of the OFWs are Overseas Contract Workers (OCW).

Table 5 Overseas Filipinos Worker

\begin{tabular}{cccc}
\hline Year & OFW (in thousands) & Male & Female \\
\hline 2000 & 978 & 527 & 451 \\
\hline 2001 & 1029 & 528 & 501 \\
\hline 2002 & 1056 & 554 & 502 \\
\hline 2003 & 982 & 508 & 475 \\
\hline 2004 & 1180 & 604 & 557 \\
\hline 2005 & 1327 & 667 & 660 \\
\hline 2006 & 1515 & 751 & 764 \\
\hline 2007 & 1747 & 890 & 857 \\
\hline 2008 & 2002 & 1034 & 968 \\
\hline 2009 & 1912 & 1010 & 901 \\
\hline 2010 & 2043 & 1068 & 975 \\
\hline 2011 & 2158 & 1126 & 1032 \\
\hline 2012 & 2220 & 1148 & 1072 \\
\hline 2013 & 2295 & 1154 & 1141 \\
\hline 2014 & 2320 & 1149 & 1170 \\
\hline
\end{tabular}

Source: Philippine Labor Migrant Policy.

Wikipedia 2012

\subsection{Social Protection in Philippines}

In recent years, social protection schema for unvulnerable women is 'cash transfer' (Conditional Cash Transfer /CCT) conditionally and non-conditionally, as an instrument of policy options to tackle 'poverty' and 'vulnerability'. This is related to the idea that these policy options offer the results to be more efficient and measurable, and there is budgetary support. Correspondingly, there have been efforts among non-governmental organizations and international multilateral donors to provide assistance to improve the internal fiscal additional funds in order to implement social protection mechanisms to social protection which have been implemented. The reason is that between $0.5 \%$ to $2.7 \%$ of the national GDP of Philippine country will be sufficient to fund cash transfers, which focused on the elderly, and the absence of the grant instruments such as child support, pension allowance scheme for the elderly, and women migrant worker.

Although social protection by providing CCT can provide social protection for elderly and vulnerable groups as well as disable group and WMW, the idea of social protection thus often gets very sharp criticism from various circles. This is because they think that it could narrow vision and has lack of social policy. In fact, according to Birdsall, N and John Nellis (2003), the scheme of CCT, for example, has been considered as a charity and used as a 'magic bullet in development'. CCT is also used to correct and evaluate market failure related to externality factors, i.e. providing incentives for people who are less fortunate to be able to adjust their behavior to social policy.

Transfer of cash is so much in demand throughout the public aid or 'donor' as an instrument of policy options: they assume that such policy is an open market that is efficient in resource allocation and is suitable for supporting the program budget. In South Africa, for example, cash transfer scheme is the main instrument of government intervention in social protection which has been widely perceived as benefits for the recipients and can drive the purchasing power of Philippine country.

Therefore, Philippine need to consider social protection for their social welfare development because it is an important element to improve the welfare of it's community and to ensure economic development sustainability. According to Edi Suharto (2007), social protection schemes can be grouped into three main elements, namely social assistance, social insurance and social protection schemes micro and by particular area. Various schemes can be changed in accordance with the existing level of economic development, social structure, and also the ability of the government concerned. Each scheme must start from the local level and supported by the scheme to the national level. Relations of cooperation among governments, funding agencies, and the public are a top priority to achieve the objectives of social protection agenda.

Futhermore, one of social protections in Philippine is CCT. It is an instrument of social protection schemes beside insurance, pension allowance, severance, and other social protections. Scheme of CCT is mean-tested, which apparently has been reversed direction towards the traditional idea of learning-policy, northern European countries in drawing lessons about global policy from the South. Chambers (1983) refers to it as a process of 'social learning from the bottom'.

Paradigm of Social Protection is certainly not only related to the cash transfer scheme. According to Adesina (2010), developing countries ask for social justice, not only in words (to be diplomatic) but also the re-distribution of normative social policy progressive on social protection schemes that are being implemented. The social protection paradigm is a 'multi-pillar', as it relates to the reform of the pension, health 
insurance, or the labor market. Proposals for transformative discourse beyond the framework of social protection has been formulated because it now has more extensive and involves the transfer of resources, social safety nets and other aspects of risk management. Transformative social protection involves not only mitigate the vulnerability but also the legal and social discrimination that result in or exacerbate social vulnerability. The same institutions argue that such social protection including indirect transfer of resources.

Social protection agenda as presented by Devereux (2002), is a fresh conceptual framework, an analytical tool, the empirical evidence, the process of national policy, an important institution and is a big name of today's social development studies. Paradigm of Social Protection is a set of assumptions, norms, policies and practices, relating to the transfer policy and the process of learning, which applies the growth paradigm, turned out to cause problems of persistent poverty and social susceptiblity. The paradigm of social protection in many protection scheme was intended to address the problem of poverty, which is the source of other social problems (World Bank, 2007).

Normative foundation of the social protection paradigm that embraces the prevailing economic paradigm is currently perceived as the transactional market logic. Most of the economic paradigm is unbeatable and especially its role in explaining the vulnerability, for which practitioners seek to overcome social protection, but not everything is covered. The result was a reduction of vision of social policy that shows success in combining economic growth is inclusive. Success case is solely based on the norms of equality and solidarity.

Alternative models to meet the challenges of inclusive development in Africa, for example, requires a basic goal of the prevailing paradigm of the Social Protection and must return to a broader vision. Therefore, the Philippine government must also undertake and implement a social policy with broader development strategy in anyway. This country cannot apply just a single policy on social policy (for example, social protection for the poor alone) but also have to apply social policy (multipillar/multi-function), namely: the production function, protection, re-distribution cohesion, social reproduction, and nation development. By doing so, the social protection of the Philippine country can realize social welfare, especially towards disadvantaged groups of people in a particular region (Adesina, 2010).
Social protection is thus not only done just by doing a minimum level social security about social welfare, such as through social insurance, unemployment insurance, pension insurance, but also mediating the public and guaranteeing to obtain a proper education, proper health care, access to employment, obtaining livable housing, and other basic needs. Thus, economic development, on the other hand, must refer to efforts to improve human capabilities or people centered development (Korten, 1987), so that they can function economically through the use of instruments of financial institutions and other institutions in the society life.

Meanwhile, the overlapping social and economic policies implemented by the Philippine country often have a negative impact on another field. Therefore, fiscal or financial policies and CCT can be used as a driver of social policy because the country budget to finance social policies requires the allocation of the budget from financial instruments. By such policy, social policy can become a lever and driver for the success of economic policy such as labor productivity, economic growth, equity, and so on.

The important role of social policy on social protection is widely delivered by Samson (2007). $\mathrm{He}$ said that social protection is an important dimension of the idea of a friendly capitalism. Thus, the concept of social protection is not only about the exchange of ideas among intellectuals and policy makers but also about the mechanism of the process of learning about the policy itself. Moreover, social protection controller can be used as a policy instrument and also serves to reduce the system of usury. In this context, the system of usury can undermine the learning of apolicy and lead to stagnation of economic growth in local communities, distorts local reality and decides long-term prospects of sustainable development. Therefore, the social protection paradigm is a great and brilliant idea.

British Department for International Development (DFID) has been devoting considerable energy and resources to push the agenda of policies related to "social transformation" as the preferred policy instrument. Similarly, the World Bank has set a great effort and mobilized resources, to deal with social risk management as its framework to provide cash transfers (CCT), accompanied by specific requirements, which are still adopted as policy options. It is actually not a soft policy domain. In many countries in the world, 'donor' institutions committed the same social protection policies and specific project funding as a pilot. There are several foreign companies (MNCs) that 
perform social protection in the form of Corporate Social Responsibility or CSR (Adesina, 2010).

The journey from Paradigm of Social Protection has gone through a long and winding road. There are many different conditions and manifestations of the discourse of social protection and specific policy regime through adjustment of social dimension framework. The notion of 'transformative social protection', for example, thus identifies the differences and similarities between different variants of the discourse. Social dimension of the adjustment program was launched in 1987 by various institutions under the World Bank.

This is in response to evidence that the social cost is very high in conducting orthodox structural adjustment program. Its social effects of structural adjustment showed a very high level of damage that can damage the structural adjustment program. By concerning to the neo-liberal policies it can generate a return orthodox social and positive economic conditions for the "poor", namely by providing incentives of country involvement in the procurement needs of the economic and social needs. This is very different from the modern structural adjustment programs which not only affect economic growth but also exacerbate poverty and thwart economic development and social development more broadly.

Response to look at the neo-liberal development paradigm orthodox, intended to rethink the basic instrument of economic and social policies as well as basic ontological ideas on structural adjustment itself. Such action was to design the "social safety network" for the poor and to address the "social costs" of structural adjustment reforms, in which the target is the vulnerable and the experiencing extreme poverty. The paradigm of social protection through social safety nets followed by improving living conditions for the poor is the concept of a poverty reduction strategy.

Social safety nets, once again, is a framework of Social Risk Management. According to Holzmann and Jorgensen (2003), they intended to provide an explanation of the shift in the discourse of the World Bank and to the problem of social vulnerability and an anti-poverty policy tool. Furthermore, it is said that social protection is an international agenda. Behind the idea of a Social Risk Management, there is no idea about all individuals, households and communities who are vulnerable to some of the environmental risks of natural and man-made environment - although many man-made environments can actually worsen human life. Poverty can be understood as vulnerability to shocks from the environment such mentioned above. A good framework of social risk management is able to effectively and efficiently handle the risks in various forms. Therefore, it is necessary to reduce and streamline the management of the consequences of vulnerability.

Such policies seek to combine the means of intervention of the labor market, social insurance, and social safety nets, under a unified scheme. The result will improve the welfare and justice, and promote economic development. Nonetheless, social risk management framework remains bound by the discourse of social safety network in various ways. First, the definition of the social segment becomes the main focus of policy attention. Beside helping individuals and households to better manage the risk, the core purpose of social protection is to provide support and assistance to the critical poor. Second, a mechanism to reach them is by doing selective way (means-tested) while the social risk management framework of the World Bank often starts from the attention to social safety nets, the focus is the very poor communities.

The World Bank needs to consider a program of cash transfers as part of risk management by allocating $1 \%$ of the gross national product (GNP) of a country; it is intended to finance social protection schemes, which can be used to protect vulnerable people, so that they do not become very poor as a result of the ongoing economic crisis. Because such program not only protects them falling into deeper poverty, but it can provide additional income and also increases the purchasing power for the poor, even the World Bank with social protection thus dreams a world free from poverty.

\subsection{Woman Migrant Worker and Social Protection in Philippines}

Many marginal populations in Philippines require treatment and social protection through social development, so that they can increase their quality of life (Orbeta, 2009). Most households in the economy are still in a state of marginality, for example, households of farmers, fishermen, poor urban, and households in the disaster area. They are in a very vulnerable condition; therefore, the need social protection for their existence. There are many models of existing social protection, ranging from the health care system named "social health insurance".

Model health insurance system has been created and programmed since 35 years ago. The Philippines has had long experience in managing this health insurance. Nowadays, the health 
insurance is considered the most successful program compared with the other insurance programs.

This social health insurance can work well in the Philippines because it has been able to reach out all groups in less fortunate society with very low, low, and medium income. There are several reasons why the health insurance system can be successful: (1) the system is based on the purpose of the cultural values prevailing in society, so as to provide technical guidance for the public to participate in the insurance program; (2) This insurance system is financed by financial institutions and required in accordance with the conditions and circumstances of local communities; (3) health insurance system can be implemented independently which does not depend on the current economic situation; (4) The financing scheme is based on the protection of public health integrated with the national health insurance system in the long term; (5) this insurance system has been able to realize high quality services and can improve physical abilities. Although it has many drawbacks as well, the existing health insurance system in the Philippines has gained strong support from the Ministry of Health and independent political institutions to continue to develop and advance the health insurance system.

Indeed, many social protection schemes exist in the Philippines. According to Mangahas (1977), social issues that have gained attention and social protection are: (1) health and nutrition; (2) learning; (3) income and consumption; (4) employment; (5) non-productive human resources; (6) housing, utilities, and theenvironment; (7) public safety and justice; (8) political values; and (9) social mobility. In doing social protection against social problems faced by the Philippines as mentioned above, the government made interventions toward social protection (including social insurance, social welfare programs, program protection of families, supplementary feeding programs for school children, the provision of cross subsidies) and protection programs on poverty, active labor market programs, and other programs.

Globalization has been able to increase the participation of women in the labor market and improve the economy. Governments throughout the world have introduced women's rights, such as economic rights, social rights, equality in access to and control of economic resources, and equality in employment. Therefore, the United Nations then ratified international labor by strengthening through existing rules, in order to protect women workers from violence in the workplace as well as to protect them from unhealthy workplace conditions, determine financing mechanisms to enhance the role female entrepreneurship, improve education and skills, including knowledge and technical skills, as well as policy-making.

The existing social protection programs in the Philippines is currently included in the government portfolio. However, from the current protection schemes, it still faces challenges which are not easy; it relates to the support in order to obtain job and increase employment, in order to absorb the labor force and job seekers in the Philippines. With the difficulties encountered in relation to employment, the government had negotiated to accommodate extra personnel with other countries. Cooperation is expected to solve the problem of labor and unemployment in the Philippines. Under these conditions the problem of unemployment and employment in the country is a very big problem because the government has not been able to do social protection for their people while, on the other side, social health protection systems have been able to function as an effective means of protection.

In fact, the Philippines has very limited employment opportunities while the labor is plentiful, mainly related to labor in the field of health. There are a number of schools or higher educations which organize the education of nurse, whereas the amount required is very limited. These conditions prompted many health care professionals to seek job abroad. The government cannot also restrict them to go abroad to find work because the country finds it difficult to provide improve the quality of life of migrants and field work for nurses. However, the presence of a nurse who work abroad can benefit not only their families but actually also the country from foreign exchange which is carried by nurses working in other countries.

Behind the benefits of migrant workers, their families, and foreign exchange for the government, migrant workers (nurse) working abroad often pose a thorny problem, giving rise to a debate among policy makers, experts, and the public about how to do social protection against them, including educational institutions that provide nursing education and hospitals. Migrant workers are not only nurses; there many other jobs done by migrant workers. In the Philippines, WMW work in various service sectors and industrial sectors, especially with regard to the export process. In Indonesia, as a comparison, women migrant workers mostly work in the household sector such as a housekeeping. Most of 
them are still girls, who then went to the city as housemaids.

The WMW are very vulnerable, indeed, compared to male workers. This vulnerability is related to violence against women, sexual harassment, rape, extortion, and so on. Therefore, social protection for migrant women workers is urgent and needs policies to protect them. The number of migrant workers from the Philippines is quite large, which was in the 1990s only about 1 million people. With that amount, the problems surely appear quite diverse. The real issues faced by WMW are women's status and salary which are lower than men's.

The Government of the Philippines stressed the problems related to the obligation of migrant workers has the right information and get referrals as possible before they leave the country. This is done by a government agency in providing education and training needed for migrant workers before getting a job in the destination country. The program is intended to WMW to earn higher salary according to their education and skills.

\section{Conclusion}

Problems of WMW in the Philippines country were discussed at the international level by the UN agency dealing with ILO. Global market potentially indicates women migrant workers. This is certainly related to the transfer of enormous women from one country to another, sometimes they are accompanied by family or individually. WMW have donated an enormous foreign exchange since they can work in companies, factories, or households, so that the number of it's greater than that of male migrant workers. In order to protect women migrant workers doing their work abroad, they have to be privileged and be given the opportunity. Finally, we need not only social protection in the national level but also cooperations among countries and nations to establish social protection for women migrant workers from the local, national, regional, and international levels.

\section{References}

Adesina, J. O. 2010. Rethinking the Social Protection Paradigm: "Social Policy in Africa'sDevelopment". Paper prepared for the Conference "Promoting Resilience Through Social Protection in Sub-Saharan Africa", Organised by the European Report of Development in Dakar, Senegal, 28-30 June, 2010.
ASEAN Economic. 2012.

Asian Countries by population. 2017. World Population Prospects: The 2015 Revision

Birdsall, N. and John Nellis, 2003. "Winners and losers: Assessing the distributional impact of privatization", World Development, vol. 31, No. 10 (October 2003), pp. 1617-1633.

Central Intelligence Agency (2017).

Chambers, R. 1983. Pembangunan Desa Mulai dari Belakang, Jakarta LP3ES.

Devereux, Stephen, 2002. "Social Protection For The Poor: Lessons from recent international experience", IDS working paper 142(Brighton, Sussex: Institute of Development Studies).

Holzmann, R. L. Sherburne-Benz and E. Tesliuc 2003. "Social Risk Management: The World Bank's Approach to Social Protection in a Globalizing World, Washington D.C.: World Bank.

Human Development Index (HDI) Report (2015).

International Monetary Fund (IMF) Report (2015). List of countries by GDP (PPP) per capita.

Kementerian Sosial RI, 2011. The International Conference on Social Welfare in the ASEAN Region. Jakarta, 27 - 28 October 2011.

Korten, David C. 1987, Third Generation NGO Strategies: A Key to People-Centered Development. World Development Pergamon Journals.Vol. 15 supplement. pp. 145 - 159.

Leonard, J. (2009). "OFW rights violation worsens under the Arroyo administration". Filipino OFWs Qatar. Archived from the original on 2009. Retrieved. 2009-01-25.

Mangahas, Mahar, 1997. The Philippines Social Indicators Project. Dardrecht-Holland, D. Reidel Publishing Company.

Oishi, N. (2002). Gender and Migration: An Integrative Approach. Working Paper.

Orbeta, A. C. 2009. 'Social Protection in the Philippines: Current State and Challenges'. In Asher, M. G. et al. Edt. (2009). Social Protection in East Asia - CurrentState and Challenges. Eria Research Project Report 2009. No. 9. p 220 - 264.

Philippine Overseas Employment Administration. (2015). "Stock Estimate of Filipinos Overseas As of December". Retrieved . 2015. 09-19.

Samson, Michael. 2007. "The impact of social transfers on growth, development, poverty and inequality in developing countries" (Cape Town: Economic Policy Research Institute, 2007).

SEKNAS FITRA (2015). 10 Strategi Pencapaian Target $M D G$ 's

Suharto, Edi. 2007. Social Protection System in ASEAN: Social Policy in a ComparativeAnalysis. PaperwasPresented at 
The 15th Symposium of the International Consortium for Soci`al Development, The Hong Kong Polytechnic University, Hongkong 16-20 July 2007.

Uriarte,F. A. Jr. 2009. Executive Director, ASEAN Foundation, Paper, presented during the conference on "Competitiveness of ASEAN Countries: Trade and Investment Issues" held at the National Institute of Development Administration, Bangkok, Thailand, 8-9 January 2009.
United Nation, 2010.Millineum Development Goals.

Wikipedia (2009). Overseas Filipinos.

Wikipedia (2012). Philippine Labor Migrant Policy.

World Bank, 2007. "Vietnam Development Report".Social Protection (Joint donor report to the Vietnam Consultative Group Meeting, Hanoi, 6-7 December 2007, Working Paper No. 43653. 